九州大学学術情報リポジトリ

Kyushu University Institutional Repository

\title{
Analysis of Leaf Litter as Potential Renewable Energy Source for Cooking
}

Hartawan, A.

Department of Mechanical Engineering, Universitas Indonesia

Aditya, N.

Department of Mechanical Engineering, Universitas Indonesia

N. G. Ratnasari

Department of Mechanical Engineering, Universitas Indonesia

Sujatmiko, W.

Directorate of Engineering Affairs for Human Settlements and Housing, Ministry of Public Works and Housing (PUPR)

他

https://doi.org/10.5109/4742129

出版情報 : Evergreen. 8 (4)，pp.835-843，2021-12. 九州大学グリーンテクノロジー研究教育センター バージョン：

権利関係 : 


\title{
Analysis of Leaf Litter as Potential Renewable Energy Source for Cooking
}

\author{
A. Hartawan ${ }^{1}$, N. Aditya ${ }^{1}$, N.G. Ratnasari ${ }^{1}$, W. Sujatmiko ${ }^{2}$, Y.S. Nugroho ${ }^{1, *}$ \\ ${ }^{1}$ Department of Mechanical Engineering, Universitas Indonesia, Indonesia \\ ${ }^{2}$ Directorate of Engineering Affairs for Human Settlements and Housing, \\ Ministry of Public Works and Housing (PUPR), Indonesia \\ *Author to whom correspondence should be addressed: \\ E-mail: yulianto.nugroho@ui.ac.id
}

(Received April 30, 2021; Revised December 16, 2021; accepted December 16, 2021).

\begin{abstract}
This work explored the potential of leaf litter as biofuel for eco-stoves in the form of shredded and pelleted fuels. Kerai Payung leaves (Filicium decipiens) was used as the fuel. The pelleted fuel was formed by mixing shredded leaves, starch, and water. An eco-cookstove that has an approximately $660 \mathrm{~cm}^{3}$ volume capacity chamber for solid fuels was used in this work. The stove has a fan attached that supplies an updraft forced vortex flow. The heat release rates of the fuels were measured by using standard cone calorimetry (ISO 5660). It was found that the fuel shape and internal transport processes in fuel beds had a strong influence on the combustion characteristics and the energy released. Peak heat release rates for shredded leaves were lower than the pelleted fuels with a shorter burning period. The results show that leaf litter has the potential as a reliable energy source.
\end{abstract}

Keywords: Leaf litter, Water boiling test, Heat release rate, Cook-stove

\section{Introduction and background}

Internationally around 2.7 billion people in developing countries heavily rely on traditional cookstoves as their daily cooking ${ }^{1)}$. In Indonesia alone, around 79 million people still use traditional biomass fuels (wood, coal, etc.) that cause pollutants inside homes ${ }^{2)}$. Traditional cookstoves mainly use natural air to mix with the fuel. In return, this causes incomplete combustion that produces a substantial amount of carbon monoxide. The effect of such pollutants is hazardous for human beings and caused many health problems, mainly respiratory problems ${ }^{344) 5)}$.

Traditional cookstoves can be tested using the water boiling test method. The procedure comprises boiling the water and measuring the weight of leftover fuel. The total CO emitted by the cookstove will determine whether or not the cookstove is sustainable enough to be used ${ }^{6}$. An innovation of improving the performance of the cookstove by adding a force fan attached to the fuel chamber could extend the utilization of cookstoves for wider users.

Most studies reported in the literature have been conducted on biomass cookstoves using solid fuel, mainly woods. Studies conducted on wood biomass show that wood has the potential energy comparable to $\mathrm{Coal}^{7}$. This potential should be weighted by considering reducing the number of trees and energy to convert log into chips of wood fuel ${ }^{8) 9(10)}$. Meanwhile, it typically leaves falls and creates litter almost every day.
Fallen leaves (leaf litter) are often ignored and left to decompose, some of which are burned for quick disposal. On the other hand, the capability of dry leaves to generate energy is usually dismissed. Dry leaves can be utilized as an alternative fuel, also known as biomass ${ }^{11) 12(13) 14) . ~ T h i s ~}$ research was focused on exploring the potential of leaves as a reliable source of fuel for stoves. Furthermore, different forms of fuel leaves were explored to discover the most efficient performance of dry leaves. Pelleted and shredded were the two forms of dry leaves being tested in this research. This work is unique as it provides a comparison between the performance test of the ecocookstove using water boiling tests with the heat release rate results using the cone calorimeter tests (ISO 5660).

\section{Method and experimental setup}

\subsection{The Stove Used}

For this experiment, we use the Biolite camping cookstove. This stove mixes the air and fuel with an updraft force vortex fan - airflow. A Biolite stove chamber is shaped like a cylinder with a diameter of $7,5 \mathrm{~cm}$ and a height of $15 \mathrm{~cm}$. Four different flow rate settings are available for this cookstove ${ }^{15}$. Only one airflow rate was considered in the present work, i.e., $1.86 \mathrm{~L} / \mathrm{s}$. A rechargeable battery-powered the fan. 


\subsection{Type of Fuel}

The fuel used for this experiment is the Kerai Payung (Filicium decipiens) leaf that is commonly found around the campus of Universitas Indonesia in Depok, Indonesia. Pelleted leaves are compact compared to shredded leaves. Pelleted leaves have a porous structure that provides a larger surface area than shredded leaves. The difference in structure may affect the combustion process, thus influencing the amount of energy released ${ }^{16)}$.

Table 1. Proximate analysis of Filicium decipiens sample

\begin{tabular}{|l|l|l|}
\hline Proximate Analysis & $\begin{array}{l}\text { Pelleted } \\
\text { Leaves }\end{array}$ & $\begin{array}{l}\text { Shredded } \\
\text { Leaves }\end{array}$ \\
\hline Total Moisture (\% ar) & 7,85 & 6,64 \\
\hline Ash (\% adb) & 5,53 & 9,51 \\
\hline Volatile Matter (\% adb) & 70,90 & 62,35 \\
\hline Fixed Carbon (\% adb) & 15,72 & 21,50 \\
\hline $\begin{array}{l}\text { Gross Calorific Value (cal/g } \\
\text { adb) }\end{array}$ & 3498 & 3731 \\
\hline
\end{tabular}

Table 2. Ultimate analysis of Filicium decipiens sample

\begin{tabular}{|l|l|l|}
\hline Ultimate Analysis & $\begin{array}{l}\text { Pelleted } \\
\text { Leaves }\end{array}$ & $\begin{array}{l}\text { Shredded } \\
\text { Leaves }\end{array}$ \\
\hline Carbon (\% adb) & 43,67 & 47,12 \\
\hline Hydrogen (\% adb) & 6,26 & 5,87 \\
\hline Nitrogen (\% adb) & 0,36 & 0,78 \\
\hline Oxygen (\% adb) & 44,11 & 36,57 \\
\hline Total Sulfur (\% adb) & 0,07 & 0,15 \\
\hline
\end{tabular}

Table 1 and Table 2 show the proximate and ultimate analysis. The tables show that adding starch in pelleted leaves increased the percentage of volatile matter, hydrogen, and nitrogen. More hydrogen and nitrogen make it easier for combustion to take place ${ }^{17)}$. Similarly, the higher percentage of volatile matter in pelleted leaves also suggests that this type of fuel burns easily. From Table 1 , it can also be seen that there is a contrasting value in the percentage of fixed carbon in both fuels. Shredded leaves have a higher percentage of fixed carbon which may influence the burning process as this could lead to incomplete combustion ${ }^{1819) 20) 21) 22) . ~}$

Tables 3 and 4 provide a comparison with some other energy sources, i.e., wood chips of G.sepium (Gamal) and sub-bituminous coal taken Indonesia 23)24)25). It shows some similiraties from the leaf and wood fuel, although there are marginal differences with the coal. Due to the fact that coal carries more substance and density, the calorific value of coal is noticeably higher than the wood and leaf fuel.
Table 3. Proximate analysis of G.sepium (Gamal) and subbituminous coal from Sumatra sample

\begin{tabular}{|l|l|l|}
\hline Proximate Analysis & Gamal & Coal \\
\hline Total Moisture (\% ar) & 7,95 & 23,10 \\
\hline Ash (\% adb) & 4,55 & 8,10 \\
\hline Volatile Matter (\% adb) & 69,57 & 32,2 \\
\hline Fixed Carbon (\% adb) & 17,93 & 20,70 \\
\hline $\begin{array}{c}\text { Gross Calorific Value (cal/g } \\
\text { adb) }\end{array}$ & 4026,77 & 6290 \\
\hline
\end{tabular}

Table 4. Ultimate analysis of Filicium decipiens sample

\begin{tabular}{|l|l|l|}
\hline Ultimate Analysis & Gamal & Coal \\
\hline Carbon (\% adb) & 43,16 & 69,20 \\
\hline Hydrogen (\% adb) & 5,22 & 5,10 \\
\hline Nitrogen (\% adb) & 0,75 & 1,1 \\
\hline Oxygen (\% adb) & 38,57 & 24,00 \\
\hline Total Sulfur (\% adb) & 0,09 & 0,6 \\
\hline
\end{tabular}

A Derivative Thermogravimetry (DTG) analysis shows the rate of thermal decomposition of a material, in this case, Filicium decipiens. Based on Fig.1, it can be seen that both samples, pelleted and shredded, have similar trends of thermal decomposition. The rate of decomposition reaches its peak at around $300{ }^{\circ} \mathrm{C}{ }^{26)}$. However, pelleted samples have a higher decomposition rate shown by the percentage of mass loss per increase in temperature than shredded samples. This is caused by the composition of the pelleted samples, which also contain starch and water. This graph indicates that pelleted samples would release more energy during combustion ${ }^{27}$.

The experiments were designed to determine the burning time of a batch of fuel. In each test, the sample was poured to fill the total volume capacity of the chamber $\left(660 \mathrm{~cm}^{3}\right)$. A total of 100 grams of the shredded leaf and 160 grams of the pelleted sample were used for each test. It shows that the pelleted fuel has a better fuel density than the shredded fuel; thus, the more pelleted fuel can be inserted into the chamber.

Before any experiments were carried out, the leaves samples were dried at $110^{\circ} \mathrm{C}$ for an hour using an electric oven ${ }^{28}$. The pelleted fuel was formed by mixing shredded leaves, starch, and water. On average, the size of the pellet was around $4 \mathrm{~cm}^{3}$ and 2 grams each. The shredded leaf was approximately $20 \mathrm{~mm}^{2}$ in size. 


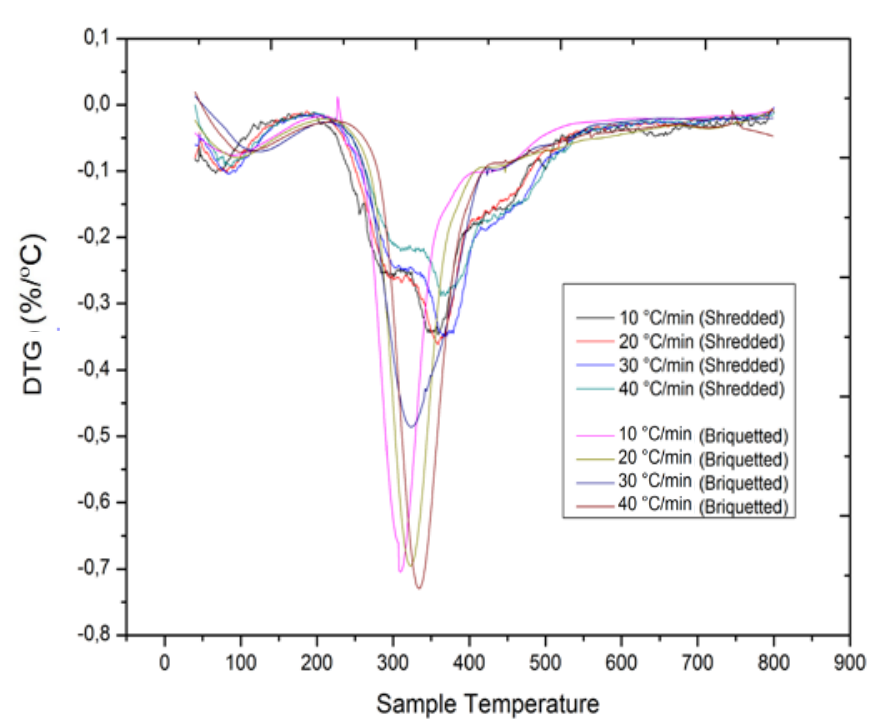

Fig. 1: DTG Analysis of Filicium decipiens sample

\subsection{Water Boiling Test}

The experiment is conducted at an average ambient temperature of $29,2^{\circ} \mathrm{C}$, the relative humidity is $78 \%$, and the gas concentration in the room is $20,96 \%$ Oxygen $0,01 \%$ CO. The experiment was conducted at the same starting time each day (in the morning, $09.00 \mathrm{am}$ ) with an average ambient temperature of $29^{\circ} \mathrm{C}$ and relative humidity of $78 \%$.

The performance of both pelleted leaves and shredded leaves was measured using a water boiling test and cone calorimeter study. The first method was the Water Boiling Test which determined the efficiency of each fuel. Figure 1 shows the schematic of the experimental procedure for the water boiling tests. A regular pan filled with water, with a volume of $500 \mathrm{~mL}$, was put on top of the eco stove. To measure the temperature of the water inside and the flame outside, we equipped the pan with thermocouples. A lid was put on top of the pan to reduce heat loss due to the water evaporation. The fuel mass was quantified before and after the experiments representing the amount of fuel needed to boil $500 \mathrm{~mL}$ of water

The test consists of three stages, the first cold start, second hot star, and third simmering. For the cold start test, the fuel is ignited at ambient temperature. The thermocouple recorded the water and flame temperature with a frequency of $1 \mathrm{~Hz}$ until the water boiling temperature was reached. The next step was the hot start stage, similar to the cold start stage. The key difference was in the residual heat left by the cold start stage, which made the fuel ignited at a higher temperature. The simmering phase was not carried out in the experiment because of the small fuel used. The mass of water and fuel was measured afterward to determine the efficiency of the fuel.

\subsubsection{Equations}

The equation for the water boiling test was standardized by the Environmental Protection Agency, Partnership for Clean Indoor Air (PCIA), and Global Alliance for Clean Cookstove (Alliance) version WBT 4.2.3 ${ }^{29)}$. Fuel consumed; To calculate the fuel consumed is by measuring the mass of the fuel after making the water boiled. The difference between the pre-weighed bundle of leaves and the leaves remaining at the end of the test phase $^{26)}$ :

$$
f_{c m}=f_{c i}-f_{c f}
$$

Equivalent dry fuel consumed; alter the quantity of dry fuel that was burned to account for two factors: (1) energy needed to remove the moisture inside the fuel and (2) the remaining amount of unburned char. The mass of dry fuel consumed is the moist fuel consumed minus the mass of water in the fuel:

$$
f_{c d}=f_{c m} \cdot(1-M C)
$$

Water vaporized from all pan; The mass of water vaporized is a quantification of water lost through evaporation during the test. It is calculated by subtracting the initial weight of pot and water negative final weight of water and pan.

$$
w_{c v}=P 1_{c i}-P 1_{c f}
$$

The effective mass of water boiled means the remaining water after the water boiled at the end of the test is the effective mass. It is a measure of the amount of water heated to boiling. It is calculated by simple subtraction of the final weight of pot and water minus the weight of the pan.

$$
w_{c r}=P 1_{c f}-P 1
$$

Time to boil; The time to boil is the difference between the start and finish times:

$$
\Delta t_{c}=t_{c, f}-t_{c, i}
$$

Thermal efficiency; This is a ratio of the work done by heating and evaporating water to the energy consumed by burning fuel. It is an estimate of the total energy produced by the fire that is used to heat the water in the pot. It is calculated in the following way ${ }^{27)}$ :

$$
h_{c}=\frac{\Delta E_{h_{2} 0, h e a t}-\Delta E_{h_{2} o, e v a p}}{E_{\text {released }, c}}
$$

Heating value is attained by viewing the gaseous value that is emitted. The values needed are carbon, oxygen, sulfur, and hydrogen obtained from cone calorimeter testing. Low heating value dan high heating value was 
calculated to determine the thermal efficiency of the water boiling test method ${ }^{30) 31)}$.

\subsection{Heat Release Rate Measurement using a Cone Calorimeter}

A calorimetry study was conducted using a standard cone calorimeter (ISO 5660). The heat release rate was calculated by measuring the oxygen depletion and $\mathrm{CO}_{2}$, $\mathrm{CO}$ released. The fuel was ignited manually using a blow torch and a fire starter. As the stove produced forced-flow condition, the mass loss rate, burning period, and heat of combustion was measured simultaneously. It was found that the fuel shape and internal transport processes in fuel beds had a strong influence on the combustion characteristics and the energy released. The size of the duct is $0,443 \mathrm{~m}$ with a c factor of 0,04312 .

The calorimeter experiment was conducted by removing the load cell from its existing one and replacing it with another load cell that is shorter in height so that the stove fits. This is experiment did not use the conical heater and igniter. Before the experiment is conducted, the barometric pressure, relative humidity, and $\mathrm{O}_{2}$ percentage are measured. The filters are changed, and the calorimeter was calibrated. After the calibration, the fuel and igniter were added to the stove. Later, the stove was placed above the load cell, and below the conical heater. The baseline is conducted first for 60 seconds to determine the control condition. The measurement starts after the fuel reaches ignition.

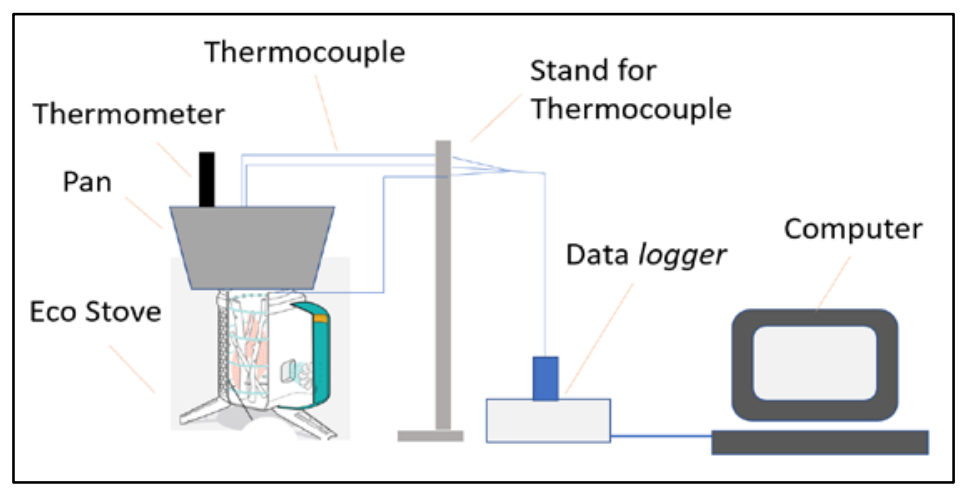

Fig. 2: Water Boiling Tests experimental setup

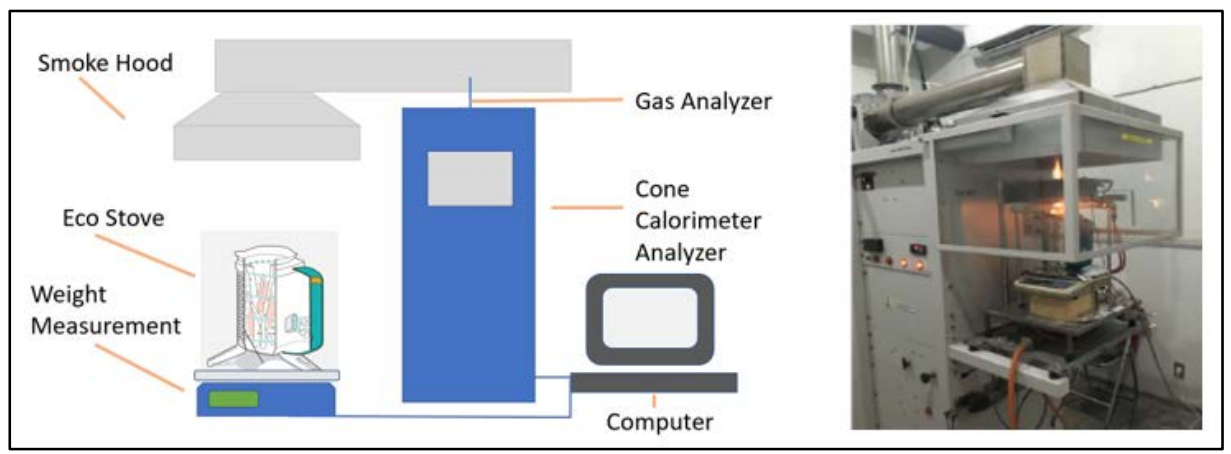

Fig. 3: Experimental setup using cone calorimeter

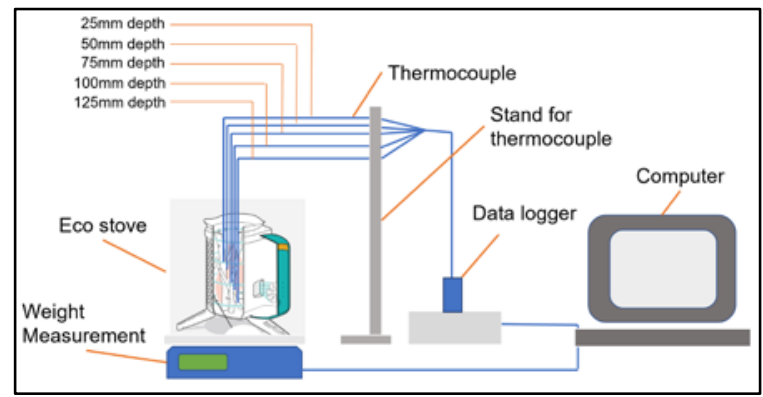

Fig. 4: Experimental setup using cone calorimeter 


\section{Results and Discussion}

\subsection{Water Boiling Test Results}

Fig. 5 shows results from water boiling tests for both types of fuel. The graph shows that the maximum flame temperature reached during the experiment was higher using pelleted leaves than shredded ones. During the experiment using pelleted leaves, the flame temperature reached a maximum of $1000^{\circ} \mathrm{C}$, whereas when shredded leaves were used as fuel, the maximum temperature reached was only around $750{ }^{\circ} \mathrm{C}$. The energy released by the fuel might cause the contrast in maximum temperature. A higher flame temperature may indicate that pelleted leaves possess higher energy compared to shredded leaves which means that this type of fuel may be more advantageous.

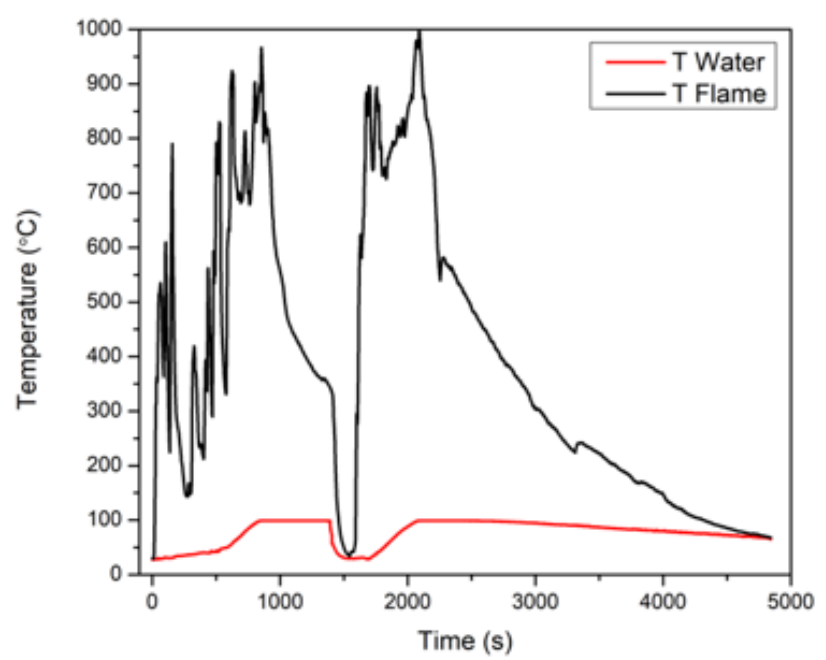

$\mathbf{A}$

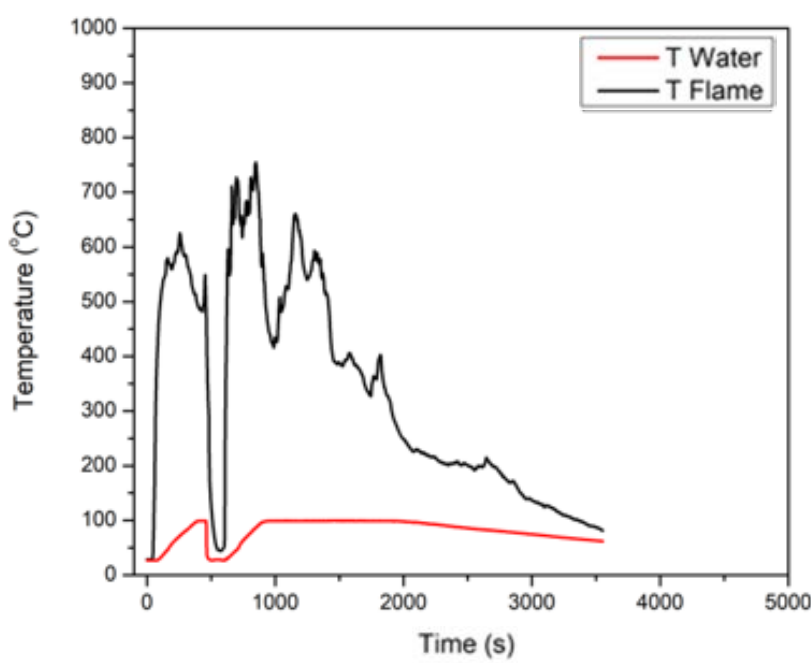

B

Fig. 5: Results obtained from water boiling tests of pelleted leaves (A) and shredded leaves (B)

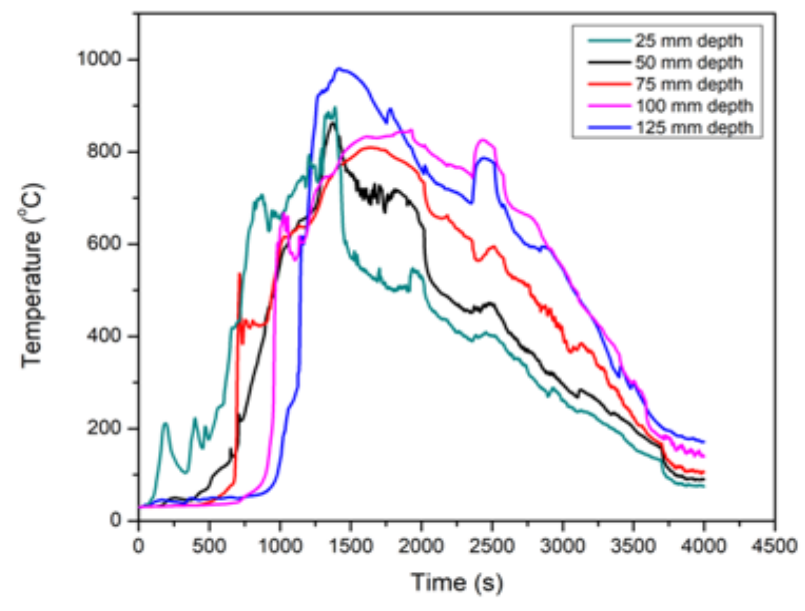

A

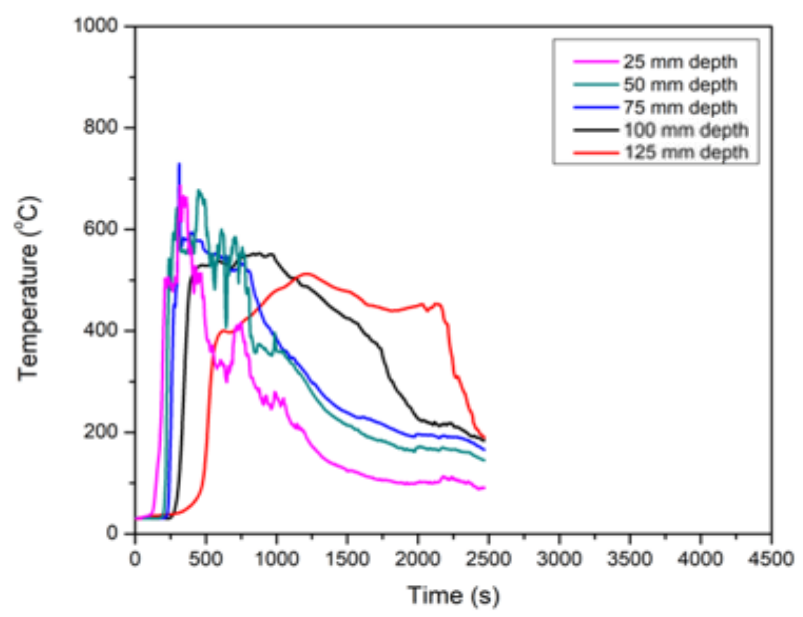

B

Fig. 6: Temperature profile inside the stove during the experiment using pelleted leaves (A) and shredded leaves (B)

The graph also shows the amount of time taken to boil water using both types of fuel. When pelleted leaves were used, the time taken for water to reach boiling temperature during cold start was 1500 seconds compared to around 500 seconds using shredded leaves. This shows that the time taken to boil water during a cold start was faster using shredded leaves than pelleted leaves. To explain this phenomenon, it is essential to also look at the flame temperature. In Fig. 5A, it could be seen that the flame temperature fluctuated during the first 500 seconds. In contrast, the flame temperature in the experiment using shredded leaves (Fig. 5B) increased immediately. During the fluctuating stage of the experiment using pelleted leaves, the temperature of water increased slowly. After the flame temperature increased significantly, the water temperature rose immediately and reached its boiling 
point.

It can also be seen that the flame temperature in the experiment using pelleted leaves is more fluctuated. This could demonstrate that pelleted leaves release their energy slowly as they have porous structures. Therefore, combustion happens slower and steadier than the flaming combustion of shredded leaves.

Similarly, the same phenomenon can be observed during the hot start phase of the experiment. The water boiling test using shredded leaves happened faster, around 400 seconds. In contrast, when pelleted leaves acted as the fuel, around 500 seconds was needed for the water to reach boiling point. However, both graphs show a similar trend. The time to reach boiling temperature during the cold start was longer than the hot start phase due to the already high starting temperature. Therefore, the energy needed to increase the temperature of the water was smaller.

\subsection{Profile Temperature Inside the Chamber}

The temperature profile inside the Bio-Lite stove during the experiment can be observed in Fig. 6. The phenomenon shown in Fig. 6 corresponds to Fig. 5. Although the maximum temperature reached during the experiment was higher using pelleted leaves, the time to reach the highest temperature was longer. Furthermore, the total time of the experiment was lengthier during the test using pelleted leaves compared to shredded leaves. This may be caused by the amount of energy being released from each type of fuel. Shredded leaves release their energy quickly, whereas, in pelleted leaves, this process happens more gradually.

The heat stored inside the pellets meant the burning time was longer than 2000 seconds. However, the temperature profile of the shredded leaves showed that the leaves have no delay time in the ignition. In contrast, the pellets struggled at first because it took a lot more energy to ignite them due to the bulkier shape. The shredded leaves have a peak temperature of $800^{\circ} \mathrm{C}$. The $\mathrm{t}$

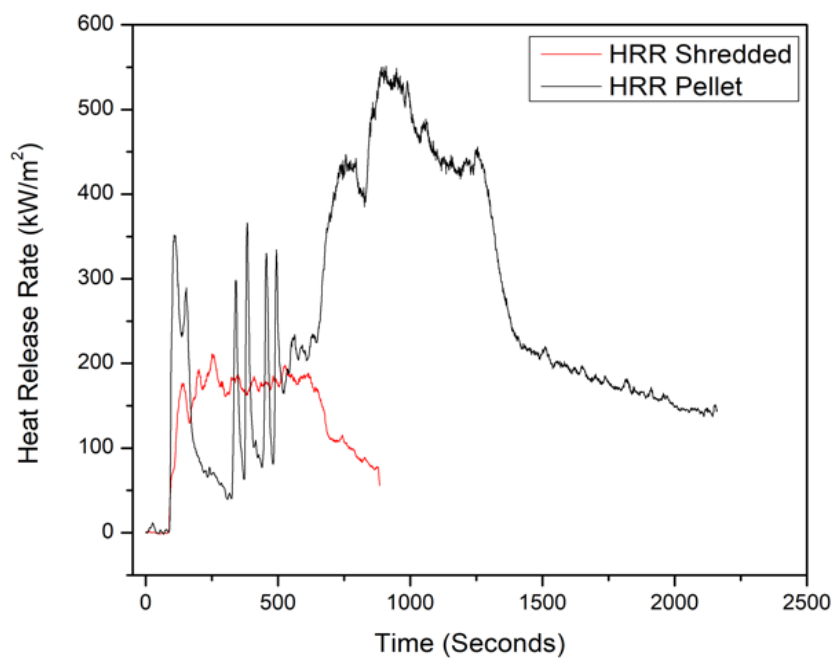

Fig. 7: Heat release rate of pelleted and shredded leaves

\subsection{Heat Release Rate Comparison}

Fig. 7 shows that pelleted fuels release more energy than shredded leaves. However, it had lower energy initially. As many as five times of re-ignition was needed for the pelleted fuel to sustain a good flame. The shredded leaves show a lower energy release rate that is caused by incomplete combustion. The total energy release rate shows that the pelleted fuels have a longer and higher total heat release rate.

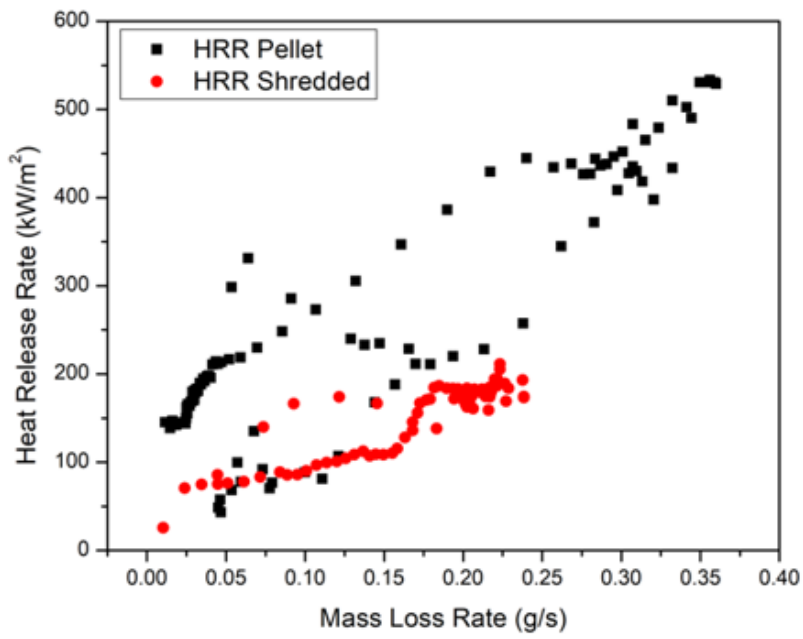

A

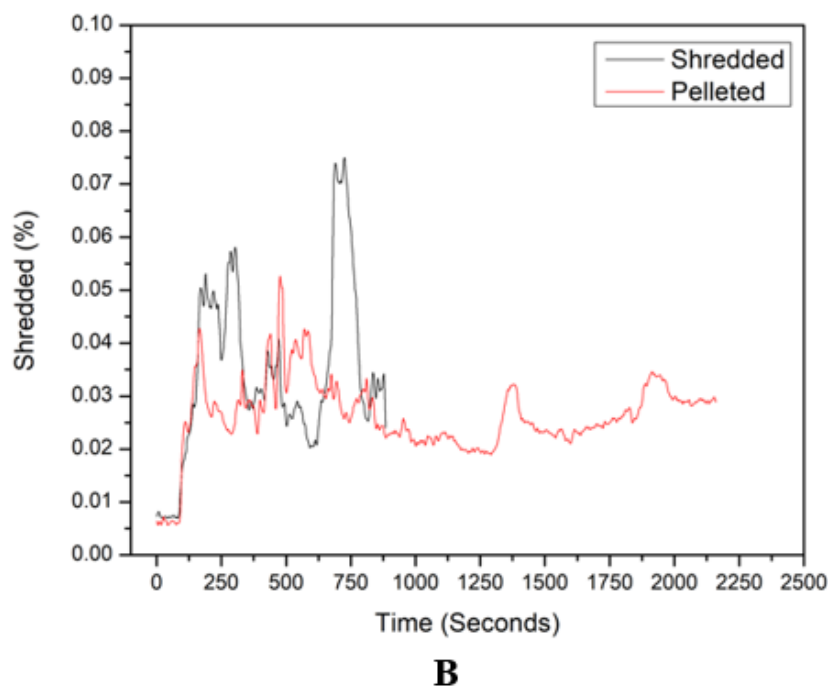

Fig. 8: Mass loss rate vs heat release rate pelleted leaves and shredded leaves (A) and Percentage of CO Emission in experiments using pelleted and shredded leaves (B).

Fig. 8 shows the mass loss rate and heat release rate of pelleted leaves compared to shredded leaves. As seen in the graph, pelleted leaves have a higher heat release rate which means that this fuel possesses a higher amount of energy. This might be because pelleted leaves have a more porous structure. Therefore, it has more surface area than shredded leaves. Similar to the heat release rate, pelleted leaves also have a higher mass-loss rate. This indicates that more fuel is burned during the combustion process, 
resulting in higher energy being released. From the graph, it is evident that there is a positive correlation between the heat release rate and the mass-loss rate. This means that as the mass-loss rate increases, the heat release rate also experiences arise. The heat release rate increases as the mass-loss rate goes up. When fuel is burned, it releases energy and loses mass; therefore, a positive correlation is established. However, this correlation is higher in pelleted leaves compared to shredded leaves.

\subsection{CO Emissions}

From Fig. 8, it can be seen that shredded leaves released a higher percentage of $\mathrm{CO}$ emission with an average of $2010 \mathrm{~kg} / \mathrm{kg}$. However, the time taken until the flame was out in the experiment using the shredded leaves was shorter than the pelleted leaves. On the other hand, pelleted leaves released a lower percentage of CO emission for a longer period. The average $\mathrm{CO}$ emission for pelleted leaves was $594.80 \mathrm{~kg} / \mathrm{kg}$. Although the average $\mathrm{CO}$ emission was lower in pelleted leaves, this type of fuel could burn longer, which would release CO emissions for a longer time than shredded leaves. This corresponds to the previous graphs showing pelleted leaves released its energy gradually. The porosity in pelleted leaves caused smoldering combustion, which made it able to sustain the flame for longer.

\section{Conclusions}

This work found a strong correlation between the heat release rate and the mass flow rate of the burning of both fuels. Pelleting of the biofuel enhances the energy intensity by energy content and heat release rate per volume. Although there are some reductions in the calorific value of the pelleted fuel due to additional binder, the uniformity of the fuel geometry could improve the combustion efficiency. The correlation is confirmed by the heat release rate produced by the cookstove under the cone calorimeter measurement. The water boiling test confirms the results in a faster time to reach the boiling condition and the ability to sustain the boiling condition of the water. The average CO emission was lower in pelleted leaves compared to shredded leaves. It is clear that leaf litter has the potential as a reliable energy source by generating a high and stable heat release rate

\section{Acknowledgments}

The authors would like to thank the financial support provided by the Ministry of Education and Culture of the Republic of Indonesia through Penelitian Dasar Unggulan Perguruan Tinggi (PDUPT) 2021 funding scheme under Grant No. NKB-218/UN2.RST/HKP.05.00/2021, and the PIT9 2019 grant managed by the Directorate for Research and Public Services (DRPM) Universitas Indonesia. The authors are grateful for technical support from the Center of Research and Development, Ministry of Public Works and Housing (PUPR) Republic of Indonesia, for the measurement of heat release rate using the cone calorimeter facility.

\section{Nomenclature:}

\begin{tabular}{|c|c|}
\hline $\mathrm{adb}$ & Air dried base \\
\hline ar & As received \\
\hline $\mathrm{CO}$ & Carbon monoxide \\
\hline $\mathrm{CO}_{2}$ & Carbon dioxide \\
\hline${ }^{\circ} \mathrm{C}$ & Degree of Celsius \\
\hline $\mathrm{Cal} / \mathrm{g}$ & Calorie per gram \\
\hline DTG & Derivative Thermogravimetry \\
\hline $\mathrm{f}_{\mathrm{cd}}$ & $\begin{array}{l}\text { Fuel mass equivalent being used } \\
\text { (gram) }\end{array}$ \\
\hline $\mathrm{f}_{\mathrm{cf}}$ & Fuel mass after the experiment (gram) \\
\hline $\mathrm{f}_{\mathrm{ci}}$ & $\begin{array}{l}\text { Fuel mass before the experiment } \\
\text { (gram) }\end{array}$ \\
\hline $\mathrm{f}_{\mathrm{cm}}$ & Mass of fuel burned (gram) \\
\hline $\mathrm{r}_{\mathrm{cb}}$ & Fuel burning rate (grams/minute) \\
\hline $\mathrm{t}_{\mathrm{c}, \mathrm{i}}$ & Time experiment starts (minute) \\
\hline $\mathrm{t}_{\mathrm{cf}}$ & Time Experiment end (minute) \\
\hline $\mathrm{W}_{\mathrm{cr}}$ & Effective mass of water boiled (gram) \\
\hline $\mathrm{W}_{\mathrm{cv}}$ & Evaporated water (gram) \\
\hline$\Delta \mathrm{t}_{\mathrm{c}}$ & Time to boil (minute) \\
\hline $\mathrm{HHV}$ & Gross calorific value (kJ/kg) \\
\hline $\mathrm{Hz}$ & Hertz \\
\hline$h_{c}$ & Thermal efficiency \\
\hline$\Delta E_{h_{2} 0, \text { heat }}$ & Heating energy \\
\hline$\Delta E_{h_{2} \text { o,evap }}$ & Evaporating energy \\
\hline$E_{\text {released }, c}$ & Energy consumed by burning fuel \\
\hline $\mathrm{L} / \mathrm{s}$ & Flow rate $(\mathrm{m} / \mathrm{s})$ \\
\hline LHV & Net calorific value $(\mathrm{kJ} / \mathrm{kg})$ \\
\hline MC & Wood moisture content (\% - wet basis) \\
\hline $\mathrm{O}_{2}$ & Oxygen \\
\hline $\mathrm{P} 1_{\mathrm{cf}}$ & $\begin{array}{l}\text { The water and pans mass after the } \\
\text { experiment (gram) }\end{array}$ \\
\hline $\mathrm{P} 1_{\mathrm{ci}}$ & $\begin{array}{l}\text { The pans mass before the experiment } \\
\text { (gram) }\end{array}$ \\
\hline PCIA & Partnership for clean indoor air \\
\hline
\end{tabular}




$\begin{array}{cl}\mathrm{T}_{\mathrm{cf}} & \text { Water temperature after exper } \\ & \left({ }^{\circ} \mathrm{C}\right) \\ \mathrm{T} 1_{\mathrm{ci}} & \text { Starting water temperature }\left({ }^{\circ} \mathrm{C}\right) \\ \mathrm{T}_{\mathrm{a}} & \text { Ambient temperature }\left({ }^{\circ} \mathrm{C}\right) \\ \mathrm{T}_{\mathrm{b}} & \text { Local water boiling point }\left({ }^{\circ} \mathrm{C}\right)\end{array}$

\section{References}

1) “Access to clean cooking,” IEA.org, (n.d.). https://www.iea.org/reports/sdg7-data-andprojections/access-to-clean-cooking (accessed August 28, 2019).

2) Badan Pusat Statistik, "Presentase rumah tangga menurut provinsi dan bahan bakar utama untuk memasak tahun 2001, 2007-2016,” (n.d.). https://www.bps.go.id/statictable/2014/09/10/1364/p ersentase-rumah-tangga-menurut-provinsi-danbahan-bakar-utama-untuk-memasak-tahun-20012007-2016.html. 6 September 2019 (accessed September 6, 2019).

3) D.Y. Chen, Z. Dong, and X.-F Zhu, "Heat/mass transfer characteristics and nonisothermal drying kinetics at the first stage of biomass pyrolysis," $J$. Therm. Anal. Calorim., 109.2 847-854 (2012).

4) Y. Chen, Shen, G., Huang, Y., Zhang, Y., Han, Y., Wang, R., Shen, H., Su, S., Lin, N., Zhu, D., Pei, L., Zheng, X., Wu, J., Wang, X., Liu, W., Wong, M., and Tao, S., "Household air pollution and personal exposure risk of polycyclic aromatic hydrocarbons among rural residents in Shanxi, China.," Indoor Air, 26(2), 246-258., 26.2 246-258 (2016).

5) Y. Chen, Shen, G., Su, S., Du, W., Huangfu, Y., Liu, G., Wang, X., Xing, B., Smith, K.R., and Tao, S., "Efficiencies and pollutant emissions from forceddraft biomass-pellet semi-gasifier stoves: comparison of international and Chinese water boiling test protocols," Energy Sustain. Dev. 32, 22-30, 32 22-30 (2016).

6) L.C. Morgan, and K.C. DeFoort, "Stove manufacturers and performance test protocol,” (n.d.). https://www.cleancookingalliance.org/binarydata/DOCUMENT/file/000/000/73-1.pdf (accessed September 6, 2019).

7) Ispita Das, K.Yeatts, and Pamela Jagger, "Biomass cooking fuels and health outcomes for women in Malawi,” Ecohealth, 14.1 7-19 (2017).

8) P. Quinteiro, F. Greco, L.A. da Cruz Tarelho, S. Righi, L. Arroja, and A.C. Dias, "A comparative life cycle assessment of centralised and decentralised wood pellets production for residential heating," Sci. Total Environ., 730 139162

(2020). doi:https://doi.org/10.1016/j.scitotenv.2020.139162.

9) N.A. Lestari, "Reduction of co_2 emission by integrated biomass gasification-solid oxide fuel cell combined with heat recovery and in-situ co_2 utilization,” Evergreen, 254-261 (2019).

10) T. Furutani, Y., Norinaga, K., Kudo, S., Hayashi, J. I., \& Watanabe, "Current situation and future scope of biomass gasification in japan,” Evergr. Jt. J. Nov. Carbon Resour. Sci. Green Asia Strateg., 4(4) 24-29 (2017).

11) A. Hartawan, "A study performance of biomass cooking stove using dry leaves in a form of briquettes with water boiling test," 2018.

12) N.B. Ardiansyah, S. R., Orlando, A. M., Rahman, A., \& Prihantini, "Tubular photobioreactor: A preliminary experiment using synechococcus sp.(cyanobacteria) cultivated in NPK media for biomass production as biofuel feedstock," Evergreen, 6.2 157-161 (2019).

13) D. Supramono, and J. Edgar, "Characteristics of nonpolar bio-oil produced by co-pyrolysis of corn cobs and polypropylene using co_2 as carrier gas," Evergreen, 6.1 78-84 (2019).

14) Y. Ayadi, M., Ahou, S., Awaf, S., Abderrabba, M., \& Andres, "Production of biogas from olive pomace," Evergreen, 7.2 228-233 (2020).

15) BioLite, “CampStove 2,” (n.d.). https://www.bioliteenergy.com/products/campstove2 (accessed August 28, 2019).

16) R.B.D. Hatmojo, R.A. Putra, L.A. Akbar, H. Mulyasih, ans Y.S. Nugroho, "Experimental study on leaf litter briquettes combustion as alternative energy source for cooking,” AIP Conf. Proc., 2255 No. 1, 030019 (2020).

17) C. Qian, Q. Li, Z. Zhang, X. Wang, J. Hu, and W. Cao, "Prediction of higher heating values of biochar from proximate and ultimate analysis," fuel, 265116925 (2020). doi:https://doi.org/10.1016/j.fuel.2019.116925.

18) J. Tryner, Bryan D. Willson, and A.J. Marchese, “The effects of fuel type and stove design on emissions and efficiency of natural-draft semi-gasifier biomass cookstoves,” Energy Sustain. Dev., 23 99-109 (2014).

19) A. Sutar, K. B., Kohli, S., Ravi, M. and R. Ray, "Biomass cookstoves: a review of technical aspects," Renew. Sustain. Energy Rev., 41 1128-1166 (2015).

20) O. Medina, P., Berrueta, V., Martínez, M., Ruiz, V., Edwards, R. D., \& Masera, “Comparative performance of five Mexican plancha-type cookstoves using water boiling tests,” Dev. Eng., 2 20-28 (2017).

21) L. Pňakovič, and L. Dzurenda, "Combustion characteristics of fallen fall leaves from ornamental trees in city and forest parks," BioResources, $\mathbf{1 0 . 3}$ 5563-5572 (2015).

22) V.V.N. Arora, P., Das, P., Jain, S., \& Kishore, “A laboratory based comparative study of indian biomass cookstove testing protocol and water boiling test," Energy Sustain. Dev., 21 81-88 (2014).

23) Amirta, Rudianto, et al, "Plant diversity and energy potency of community forest in East Kalimantan, 
Indonesia: Searching for fast growing wood species for energy production,” Nusantara Bioscience, 8 2231 (2016).

24) Belkin, Harvey E., et al "Geochemistry and petrology of selected coal samples from Sumatra, Kalimantan, Sulawesi, and Papua, Indonesia.," International Journal of Coal Geology, 77 260-268 (2009).

25) Mahidin, H. Usui, S. Ishikawa, and Hamdani "The evaluation of spontaneous combustion characteristics and properties of raw and upgraded Indonesian low ran coals.," Coal Preparation, 22 81-91 (2002).

26) Y. Jiang, Z., Liu, Z., Fei, B., Cai, Z., \& Yu, “The pyrolysis characteristics of moso bamboo,” J. Anal. Appl. Pyrolysis, 94 48-52 (2012).

27) D. Chen, Y. Zheng, and X. Zhu, "In-depth investigation on the pyrolysis kinetics of raw biomass. part i: kinetic analysis for the drying and devolatilization stages.," Bioresour. Technol. 40-46., 131 40-46 (2013).

28) Sutar, Kohli, Ravi, and Ray, "Biomass Cookstoves: A Review Of Technical Aspects,” in: Handb. Biomass Cookstove Res. Des. Dev., Global Alliance For Clean Cookstoves, 2015. http://cleancookstoves.org/binarydata/RESOURCE/file/000/000/517-1.pdf.

29) J. Yuntenwi, E. A., MacCarty, N., Still, D., \& Ertel, "Laboratory study of the effects of moisture content on heat transfer and combustion efficiency of three biomass cook stoves,” Energy Sustain. Dev., 12.2 6677 (2008).

30) S. Acar, A. Ayanoglu and A. Demirbas, Determination of higher heating values (hhvs) of biomass fuels," Energy Educ. Sci. Technol. Part A Energy Sci. Res., 28.2 749-758 (2012).

31) Nasruddin A., R. Rahardian, I. Ibnu Hakim, N. Putra, \& R. A. Koestoer” Non-Sweap Gas Pyrolysis with Vapor Heater using "Shorea Pinanga" as feedstock" Evergreen, 7.4 555-563 (2020). 